\title{
Testing the relationship between financial sector output, employment and economic growth in North Cyprus
}

\author{
Behiye Cavusoglu ${ }^{1^{*}}$ D, Saifullahi Sani Ibrahim ${ }^{2}$ and Huseyin Ozdeser ${ }^{1}$
}

\author{
* Correspondence: \\ behiye.cavusoglu@neu.edu.tr \\ ${ }^{1}$ Department of Economics, Near \\ East University, Nicosia, North \\ Cyprus \\ Full list of author information is \\ available at the end of the article
}

\begin{abstract}
Sound and efficient functioning of financial systems is critical to the economic prosperity of any economy. This paper investigates the tripartite relationship between financial sector output, employment and economic growth in North Cyprus. Using relevant time series data analysis (within the framework of structural breaks and VECM), we found that financial sector output in North Cyprus is sensitive to both internal and external shocks in that its economy is well linked with the global economy, in spite of the political isolation sustained since the bifurcation of Cyprus into North and South. The study further documents evidence of the neutrality hypothesis in the finance-growth nexus. The underlying variables were weakly connected in the short-run. However, economic growth responded to the short-run shocks and handled the equilibrating process of reverting to the long-run trend and thus, the demand following hypothesis is confirmed in the long-run.
\end{abstract}

Keywords: Financial sector output, Economic growth, Employment, Structural breaks JEL: E44, G2, O11

\section{Introduction}

Financial institutions are the most important components of financial systems based on the developmental role they play, irrespective of the nature of the economic setting in which a country operates. In this regard, an effective and efficient financial system could be considered as an indispensable tool that is necessary for a nation's economic development process. Financial liberalization, in contrast to repression, is regarded as a means to foster competition in the financial sector, which is vital in deepening the access to cheap credit for firms and households alike. Stable financial systems can be used as an alternative method of measuring the rate of development that countries are able to garner. It is not surprising that most advanced economies have had relatively sound and efficient financial systems. This could be accounted for by the common interconnections between economic prosperity and healthy financial institutions. This is attributed to the everincreasing debates between the demand-following versus supply-leading hypotheses.

The relationship between economic growth and financial development has generated significant interest in the economic literature. Numerous researchers have discussed the causal impact of financial development on economic growth. Studies over the past 30 years on the finance-growth nexus not only show the consistent relationship

(c) The Author(s). 2019 Open Access This article is distributed under the terms of the Creative Commons Attribution 4.0 International License (http://creativecommons.org/licenses/by/4.0/), which permits unrestricted use, distribution, and reproduction in any medium, provided you give appropriate credit to the original author(s) and the source, provide a link to the Creative Commons license, and indicate if changes were made. 
between them, but also the strong predictive power of the aggregate measures of finance and growth. They also argue that better financial systems stimulate faster growth in productivity by channelling society's resources into promising productivityenhancing endeavors (Colombage, 2008). Kou et al. (2019) emphasize the importance of numerical analysis of financial market with measuring financial systemic risk. Some studies have explicitly confirmed the demand-following hypothesis by employing distinct econometric methods (see for instance, Claessens et al., 2001; Islam and Mozumdar, 2007; Micco et al., 2007; Yartey 2008). Furthermore, the supply-leading hypothesis was documented in the works of Patrick, 1966; Goldsmith, 1969; Jung, 1986; King and Levine, 1993; Levine and Zervos, 1998; Levine et al., 2000; Christopoulous and Tsionas 2004; Güryay et al., 2007. Drake et al. (2006) gave an insight into the need to take into account problematic outliers, accounting for shocks from external factors on banking systems empirically, while considering banking systems that experience a downturn in efficiency due to unpredictable market conditions. Fink et al. (2009) examined the impact of financial sectors at different stages of development in nine European Union accession countries during their early years of transition (1996-2000). The conventional production function was applied in determining the impact of the credit, bond and stock segments. The study found that the transfer mechanisms differed over the development cycle (from bond markets to educational attainment to labour participation) and that financial market segments with links to the public sector (but not stock markets) contributed to stability and growth in transition economies. The long-run and short-run relationship between economic growth, bank deposits and the inflation rate in North Cyprus was analyzed by Tursoy and Faisal (2018) using ARDL bound test. The results showed a strong long-run relationship between the variables. Also, the study found unidirectional causal relationship between economic growth and the inflation rate in North Cyprus. Moreover, Caporale et al. (2015) investigated the relationship between financial development and economic growth in a transition economy by estimating a dynamic panel model over the period 1994-2007. The study found that the contribution of the financial sector to economic growth is limited owing to a lack of financial depth in the transition economy.

In spite of the vast body of literature dealing with the finance-growth nexus, few studies have been conducted on the role of financial sector output in a semi-closed economy with limited interconnection with the global financial system. North Cyprus is arguably an autarchy that is recognised only by Turkey. Since its unilateral declaration of independence in 1983, the country has had minimal participating power in global politics owing to the embargo placed on it by the United Nations. The country relies heavily on Turkey for its economic and political development (Okumus et al., 2005). In this text, Cyprus means pre-1974 Cyprus, while North Cyprus will be used interchangeably with the Turkish Republic of North Cyprus (TRNC). The next section presents a snapshot of the North Cyprus economy, Section 3 describes the research method, Section 4 analyses the results and the final Section concludes the study.

\section{North Cyprus economy}

Cyprus is the third largest island in the Mediterranean. Continual political uproar dating back to the post-independence period culminated in the coup d'état launched mainly by Greek Cypriots as part of an attempt to annex the island to Greece. This 
prompted the Turkish (as a guarantor power in the formation of Cyprus) to intervene. This unfortunate development ultimately led to the bifurcation of Cyprus into two separate entities, South and North Cyprus (Andronikou, 1979; Nedjatigil, 1982; Barkey and Gordon, 2001). It is, however, important to note that the Republic of Cyprus, as represented by the South Cyprus authorities (in contrast to North Cyprus), is internationally recognized and an official member of the European Union. The North Cyprus economy has its own special features including that it does not have strong economic ties with the rest of the world. In fact, all of its trade items must be routed through Turkey before reaching their final destinations. Thus, a semi-closed economic system seems to be a more befitting term in this case.

The economic status of North Cyprus does not permit it to have its own legal tender currency. Consequently, the Turkish Lira (TL) is the official currency, although it is common to find some transactions settled with either euros, US dollars or pound sterling. Furthermore, the country has limited leverage to sharpen its monetary policy to achieve a designated goal. The Central Bank of North Cyprus uses its monetary policy only for controlling the money supply to influence the overall economic activity. In achieving economic stability, the Central Bank of North Cyprus often targets and manipulates the quantity of money in circulation, the cost of availability of credit and the composition of the country's foreign aid taken from Turkey (Gunsel, 2006). As a result of the lack of economic strength to fine-tune efficient monetary policy and its over-dependence on Turkey, North Cyprus has struggled to cope with the severe inflation, budget deficit, unemployment and financial distress in the period corresponding to the Turkish financial crisis of 2001 (Safaklı and Ozdeser, 2002). Kakazu (1994) listed the general characteristics and problems of small island economies as less diversified economic activities, small domestic markets, trade deficits, diseconomies of scale, high transportation costs, rapid population growth, a common currency with a major country and high foreign aid dependency. Most of these characteristics have manifested themselves to a varying degree in North Cyprus.

In summary, the service sector is the bedrock of the North Cyprus economy. This does not diminish the contribution of the trade, tourism, higher education and agricultural sectors to the Gross Domestic Product (GDP). The economy, especially the financial sector, has experienced the following chronological events. Over the period 1980-2002, the financial market was liberalized in North Cyprus. In 1994, a banking and currency crisis occurred. A three-year rehabilitation programme was formulated in 2000 for the protection of the financial sector from failure. The Saving Deposits Insurance Fund Law was introduced, which aimed to insure saving deposits at banks. Furthermore, the minimum capital requirement ratio was increased and new accounting policies were announced. In 2001, the government took legal precautions and decreased the public sector borrowing requirements. In 2002, the North Cyprus economy exhibited positive progress in the banking sector as a consequence of the three-year rehabilitation programme, which encouraged public and private banks in terms of lending. It could therefore be theorised that the financial sector has now been strengthened and is in sound condition for the pursuance of financial services in the country.

\section{Methodology}

Available annual time series data for relevant variables were sourced from the State Planning Organization (SPO) of North Cyprus for the period between 1977 until 2013. 
Real Gross Domestic Product (RGDP) was used as a proxy for economic growth and was measured as the growth rate of GDP for the successive periods, while value-added by financial institutions to the GDP was used as financial sector output. It is notable that there is no subsisting capital market in the TRNC; in fact, deposit money banking is the only active player in the financial system that takes care of the tasks related to capital markets. Employment data was based on successive household labour surveys, periodically conducted by the SPO. The functional relations of the underlying variables are given below:

$$
R G D P=f(F I, E M P)
$$

The linear functional form of Eq. 1 was transformed into a natural logarithm, as it was necessary to interpret the estimated parameters as elasticities.

$$
\ln R G D P_{t}=\varnothing_{0}+\varnothing_{1} \ln F I_{t}+\varnothing_{2} \ln E M P_{t}+\epsilon_{t}
$$

Where:

$\ln \mathrm{RGDP}_{\mathrm{t}}=\log$ of Real Gross Domestic Product

$\ln \mathrm{FI}_{\mathrm{t}}=\log$ of Financial sector output

$\ln \mathrm{EMP}_{\mathrm{t}}=\log$ of Employment

$\epsilon_{t}=$ White noise error term

$\varnothing_{i}=$ Parameter of the coefficients

It is significant that the macroeconomic variables modelled above are very sensitive to swings attributed to deliberate governmental policy, as well as internal and external shocks. A good point to start is by analysing any regime change periods, which mirror the trend patterns (structural breaks, if any) in the underlying series. To this end, various tests of structural change will be applied. The body of literature related to the methods for uncovering single or multiple breaks in temporal series has expanded in the last two decades (Hamilton, 1991). Econometric underpinning concerning the theorem upon which structural break tests were developed will not be considered in this paper. Refer to Hamilton (1991), Zivot and Andrews (1992), Bai and Perron (1998), Clemente et al. (1998) and Baum et al. (1999) for more extensive studies on structural break tests. The pioneering work in the structural break analysis was by Chow (1960). This test relied heavily on a priori information about the suspected period that characterised a shift in a major economic event. The suspected structural break date could be attributed to a change in policy or by a sudden shock to the economy. Moreover, the Zivot-Andrews structural break test (1992) is helpful in unveiling the deterministic aspect of the regressors, which is based on three hypothesised breaks: intercept, trend and both. The Bai and Perron (1998) test provide unique robustness by examining the multiple structural changes, occurring at unknown dates, in the linear regression model estimated by least squares. All three of these tests were applied in this study.

To eliminate spurious regression in the form of high value of coefficient of determination, Granger and Newbold (1974) is recommended for the unit root test prior to checking the properties of the series. The univariate unit root models are given below:

$$
\begin{aligned}
& \Delta X_{t}=a X_{t-1}+\varepsilon_{t} \\
& \Delta X_{t}=\gamma_{0}+a X_{t-1}+\varepsilon_{t}
\end{aligned}
$$




$$
\Delta X_{t}=\gamma_{0}+\gamma_{1} T+a X_{t-1}+\varepsilon_{t}
$$

Where $\mathrm{X}_{\mathrm{t}}, \mathrm{T}$ and $\Delta$ denotes a time series, a linear time trend and first difference operator, $\gamma_{0}$ is a constant, $\gamma_{1}, a$ and $d$ are the slope and $\varepsilon_{t}$ is white noise series, respectively. To avoid any form of serial correlation in the residuals, the model will be augmented by adding an appropriate lagged dependent variable, i.e. $\sum_{j=1}^{k} d_{j} \Delta X_{t-j}$, and the procedure will metamorphose into the Augmented Dickey-Fuller unit root test (Dickey and Fuller, 1979). On the other hand, Phillips and Perron (1988) championed the use of the nonparametric transformation of $t$-test into $z$-test, which is consistent with DF distribution in that it eliminates any form of serial correlation in the residuals. It is not within the scope of this study to contribute to the debates in the unit root literature. The study is limited to the application of the classic unit root tests of ADF and PP in examining the stationarity nature of the series.

The Johansen and Juselius (1990) cointegration test is based on maximum likelihood analysis that estimates whether the characteristic root is significantly different from unity in the form of VAR by estimating $\lambda_{\text {trace }}(r)=-\mathrm{T} \sum_{i=r+1}^{n} \ln \left(1-\hat{\lambda}_{i}\right)$ and $\lambda_{\max }(r, r+1)=-\mathrm{T} \ln \left(1-\hat{\lambda}_{r+1}\right)$ for trace and maximum eigenvalue values, respectively. In each case, the null hypothesis is tested against the general alternative. This test is robust, provided that the underlying series exhibits a common order of integration. The pairwise estimation of causal relation in the cointegrated series is not appropriate via the Granger (1969) causality procedure. Instead, causality can be established in such a case via the Vector Error Correction Mechanism (Granger, 1986). The resulting model is.

$$
\begin{aligned}
& \Delta \ln R G D P_{t}=\partial_{01}+\sum_{j=1}^{n} \partial_{11} \Delta \ln R G D P_{t-1} \sum_{j=1}^{n} \partial_{12} \Delta \ln F I_{t-1}+\sum_{j=1}^{n} \partial_{13} \Delta \ln E M P_{t-1}+E C T_{t-1}+\mu_{1 t} \\
& \Delta \ln F I_{t}=\partial_{01} \sum_{j=1}^{n} \partial_{21} \Delta \ln R G D P_{t-1} \sum_{j=1}^{n} \partial_{22} \Delta \ln F I_{t-1}+\sum_{j=1}^{n} \partial_{23} \Delta \ln E M P_{t-1}+E C T_{t-1}+\mu_{2 t} \\
& \Delta \ln E M P_{t}=\partial_{03}+\sum_{j=1}^{n} \partial_{31} \Delta \ln R G D P_{t-1} \sum_{j=1}^{n} \partial_{32} \Delta \ln F I_{t-1}+\sum_{j=1}^{n} \partial_{33} \Delta \ln E M P_{t-1}+E C T_{t-1}+\mu_{3 t}
\end{aligned}
$$

The coefficients of the Error Correction Terms (ECT) are expected to portray negative signs and this conveys the speed of adjustment for the short-run to converge into long-run equilibria.

\section{Empirical results}

There have been a reasonable number of financial reforms implemented to ensure stability in the financial system of North Cyprus. In spite of its relative political isolation, the country is not immune to the effects of global economic turmoil, mainly owing to a contagion effect with Turkey as the primary agent of transmission. The major break in financial sector output was found in 2001 (See Chow test in Table 1), which coincides with the period of financial crisis in North Cyprus. Its repercussions were enormous and wide-ranging, but in line with the scope of this study, we will solely focus on the 
Table 1 Chow Structural Break test

\begin{tabular}{lll}
\hline Series & Break date & F-statistics \\
\hline Financial sector output & 2001 & $18.91^{\mathrm{a}}$ \\
RGDP & 2001 & $357.55^{\mathrm{a}}$ \\
& 2006 & $17.28^{\mathrm{a}}$ \\
Employment & 2004 & $40.96^{\mathrm{a}}$ \\
\hline
\end{tabular}

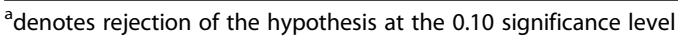

variables in question. The attendant effects of the post-millennial financial meltdown were the collapse of the banking sector, loss of confidence in the banking sector, persistent inflation and the failure of the Turkish forex reforms. This plunged the economy into recession, which was characterised by falling investments and a rising unemployment rate between 2000 until 2001.

The Zivot and Andrews (1992) structural break test results reported in Table 2 show the deterministic aspect of the break. There were significant breaks in trend for RGDP and employment in 2001 and 2004, respectively. However, the test failed to report any significant breaks in financial sector output, nor were there any breaks in intercept in employment and GDP.

The advantage of the Bai and Perron (1998) test lies in its strength in detecting the multiple unknown break dates (see Table 3). The test is based on an efficient algorithm that yields global minimizers of the sum of squared residuals. With minimal trade relations with the rest of the world, one would expect North Cyprus to be immune from global oscillations. However, that the reality is that shocks from the Asian financial crisis of 1991 had strongly impacted the root of the financial system in the country. The prolonged effect of the crisis culminated in banking distress between 1994 until 1996. In fact, two banks were initially faced with liquidity problems and ultimately declared bankruptcy. Due to the interdependences in the banking system, the overall banking sector was affected in such a way that it weakened the foundations of the financial system.

Loss of confidence by customers was imminent and financial intermediation became cumbersome. This called for strong financial reforms aimed at reversing the trends. The Bai structural break test in Table 3 confirms the economic resurgence of 2006, which resulted from a combination of robust financial reforms that stemmed the tide in the economy.

Table 2 Zivot-Andrews Structural break test

\begin{tabular}{llll}
\hline Series & Break assumption & Break date & t-statistics \\
\hline Financial sector output & Intercept & 2006 & 1.43 \\
& Trend & 1992 & 2.92 \\
& Intercept \& Trend & 1997 & -2.76 \\
RGDP & Intercept & 2003 & -1.05 \\
& Trend & 2000 & $-4.98^{\mathrm{a}}$ \\
& Intercept \& Trend & 1999 & -4.10 \\
Employment & Intercept & 2003 & -1.05 \\
& Trend & 2004 & $-8.35^{\mathrm{a}}$ \\
& Intercept \& Trend & 2004 & $-7.68^{\mathrm{a}}$ \\
\hline
\end{tabular}

adenotes rejection of the hypothesis at the 0.01 level 
Table 3 Bai and Perron Structural break test

\begin{tabular}{|c|c|c|c|c|}
\hline Series & Break test & f-statistics & Critical value & Break date \\
\hline \multirow[t]{4}{*}{ Financial sector output } & 0 vs. $1^{a}$ & 46.18498 & 13.98 & 1991 \\
\hline & 1 vs. $2^{a}$ & 25.13786 & 15.72 & 1996 \\
\hline & 2 vs. $3^{a}$ & 32.91620 & 16.83 & 2001 \\
\hline & 3 vs. $4^{a}$ & 19.87723 & 17.61 & 2006 \\
\hline \multirow[t]{2}{*}{ GDP } & 0 vs. $1^{a}$ & 1072.636 & 13.98 & 2001 \\
\hline & 1 vs. $2^{a}$ & 30.72901 & 15.72 & 2006 \\
\hline Employment & 0 vs. $1^{a}$ & 163.8459 & 16.19 & 2004 \\
\hline
\end{tabular}

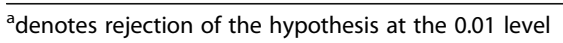

VAR analysis is sensitive to the order of integration in the underlying series. At the same time, it determines whether to difference the series or otherwise. The degree of integration based on Eqs. (3-5) of the unit root test models specified above were estimated for the relevant series. It was evident from the results that the unit root hypotheses for all the variables cannot be rejected at their level forms. However, the test rejects the null hypothesis of non-stationarity for the all variables when used in the first difference forms. This denotes that all series are stationary in the first difference and are integrated of order one. This satisfies the precondition for estimating the long-run equilibria in the series via the Johansen and Juselius (1990) technique and the result is presented in Table 4.

It appears that all the series were integrated at order one [I (1)] based on the unit root test statistics at the $1 \%$ level of significance. The cointegration estimation, which is based on maximum likelihood tests, shows the results for Trace Test Statistics $\left(\lambda_{\text {trace }}\right)$ and the Maximum Statistics $\left(\lambda_{\max }\right)$ and is presented in Table 5. Various lag lengths were tried, but in order to preserve the symmetry of the system, the common lag length for the series was chosen by the Akaike Information Criterion (AIC) and Schwartz Bayesian Information Criteria (SIC). They suggest a lag of 3 for all equations.

It could be discerned from the cointegration results that the absolute values of trace and maximum statistics tests of the residuals exceed their critical value in the hypothesis. This illustrates no (none) cointegration relation among the series at the 0.05 level and it denotes the existence of one cointegrating vector among the series (see Table 5). Thus, the series were cointegrated and this validates the application of VECM. The advantage of VECM is that both long-run and short-run dynamics can be modelled simultaneously.

Table 4 Unit root test

\begin{tabular}{|c|c|c|c|c|c|c|}
\hline \multirow[t]{2}{*}{ Series } & \multicolumn{3}{|l|}{ ADF } & \multicolumn{3}{|l|}{ PP } \\
\hline & $\bar{T}$ & $\tau \mu$ & $\overline{T T}$ & $\bar{T}$ & $\tau \mu$ & $\overline{T T}$ \\
\hline $\ln R G D P$ & -2.98 & -3.11 & -3.13 & -2.88 & -2.98 & -2.98 \\
\hline$\triangle / n R G D P$ & $-5.02^{a}$ & $-4.92^{\mathrm{a}}$ & $-4.47^{\mathrm{a}}$ & $-11.20^{\mathrm{a}}$ & $-10.86^{a}$ & $-10.98^{\mathrm{a}}$ \\
\hline $\ln F I$ & 1.66 & 0.70 & -1.30 & 1.40 & 0.57 & -2.10 \\
\hline$\triangle I n F I$ & -1.77 & $-8.94^{\mathrm{a}}$ & $-4.85^{a}$ & $-8.69^{a}$ & $-9.84^{\mathrm{a}}$ & $-27.32^{a}$ \\
\hline $\ln E M P$ & 2.71 & 1.59 & -2.22 & 3.27 & -1.86 & 2.11 \\
\hline$\triangle I n E M P$ & $-5.31^{a}$ & $-5.91^{\mathrm{a}}$ & $-6.40^{\mathrm{a}}$ & $-5.40^{\mathrm{a}}$ & $-6.28^{\mathrm{a}}$ & $-7.36^{\mathrm{a}}$ \\
\hline
\end{tabular}

adenotes rejection of the hypothesis at the 0.01 level 
Table 5 Johansen and Juselius cointegration

\begin{tabular}{llllllll}
\hline Hypothesis & $\lambda_{\text {trace }}$ & $5 \%$ Crit. Value & Prob. $^{* *}$ & Eigenvalue & $\lambda_{\max }$ & $5 \%$ Crit. Value & Prob. $^{* *}$ \\
\hline None $^{\text {a }}$ & 64.06 & 35.19 & 0.0000 & 0.746 & 46.60 & 22.30 & 0.0000 \\
At most 1 & 17.46 & 20.26 & 0.1161 & 0.294 & 11.82 & 15.89 & 0.1968 \\
At most 2 & 5.65 & 9.16 & 0.2199 & 0.153 & 5.65 & 9.16 & 0.2199 \\
\hline
\end{tabular}

${ }^{a}$ denotes rejection of the hypothesis at the 0.05 level

${ }^{* *}$ McKinnon-Haug-Michelis (1999) $p$-values

The multivariate VECM based on Eqs. 6-8 specified in the preceding section were estimated based on the one cointegration equation established through Johansen and Juselius's method (see Table 6). The neutrality hypothesis was confirmed as financial sector output and economic growth were independent from each other. Moreover, there is evidence of a bidirectional causality between financial sector output and the level of employment in North Cyprus. Financial sector output supports employment generation in the country, whereas deposits by workers in the banks are critical to the tripartite functions of financial intermediation in the short-run. A unidirectional causality was found running from employment to economic growth. This underscores the impact of human factors in the growth-driven process.

To maintain a steady growth path in the system, economic growth and employment must respond by $7.2 \%$ and $0.000025 \%$ to the short-run disequilibrium, respectively. The speed of adjustment back to the long-run equilibrium in reaction to short-run shocks over successive years is not sufficiently robust to guarantee the necessary output of financial intermediary institutions for North Cyprus to spur growth. The positive and insignificant error correction term of financial sector output has dramatic economic undertones. It explicitly signifies the absence of causality between financial sector output and economic growth in the long-run, but the reverse is not the case. Financial institutions make insignificant contributions to the growth of the North Cyprus economy. In the absence of a capital market in the country, it puts more pressure on the banking sector in both the short-run and long-run.

The impulse response results of Real Gross Domestic Product, Employment and Financial Sector output can be seen in Fig. 1.

It is very clear from the impulse response result shown in the above figure that major shocks in financial sector output resulted from its own structural innovation in the previous period. Moreover, financial sector output responded to previous employment stimuli, which is oscillating and negative after the second period. This illustrates the instantaneous links between the financial sector output and the level of employment.

Table 6 Multivariate VECM

\begin{tabular}{lllll}
\hline Independent variables & \multicolumn{1}{l}{} \\
\hline Dependent variables & $\Delta \mathrm{RGDP}$ & $\Delta \mathrm{FI}$ & $\Delta \mathrm{EMP}$ & $\mathrm{ECT}_{\mathrm{t}-1}$ \\
\hline$\Delta \mathrm{RGDP}(-1)$ & - & -0.001 & 0.076 & $-0.071^{\mathrm{b}}$ \\
& & $(-0.96)$ & $(0.874)$ & $(-2.37)$ \\
$\Delta \mathrm{FI}(-1)$ & -0.596 & - & $10,033.11^{\mathrm{a}}$ & 0.025 \\
& $(-1.19)$ & & $(5.47)$ & $(1.161)$ \\
$\Delta \mathrm{EMP}(-1)$ & $-0.008^{\mathrm{a}}$ & $-5.76^{\mathrm{a}}$ & - & $-0.0000025^{\mathrm{a}}$ \\
& $(-2.71)$ & $(-5.76)$ & & $(-5.34)$ \\
\hline
\end{tabular}

a, b \& * denotes rejection of the hypothesis at the $0.01,0.05 \& 0.10$ levels 


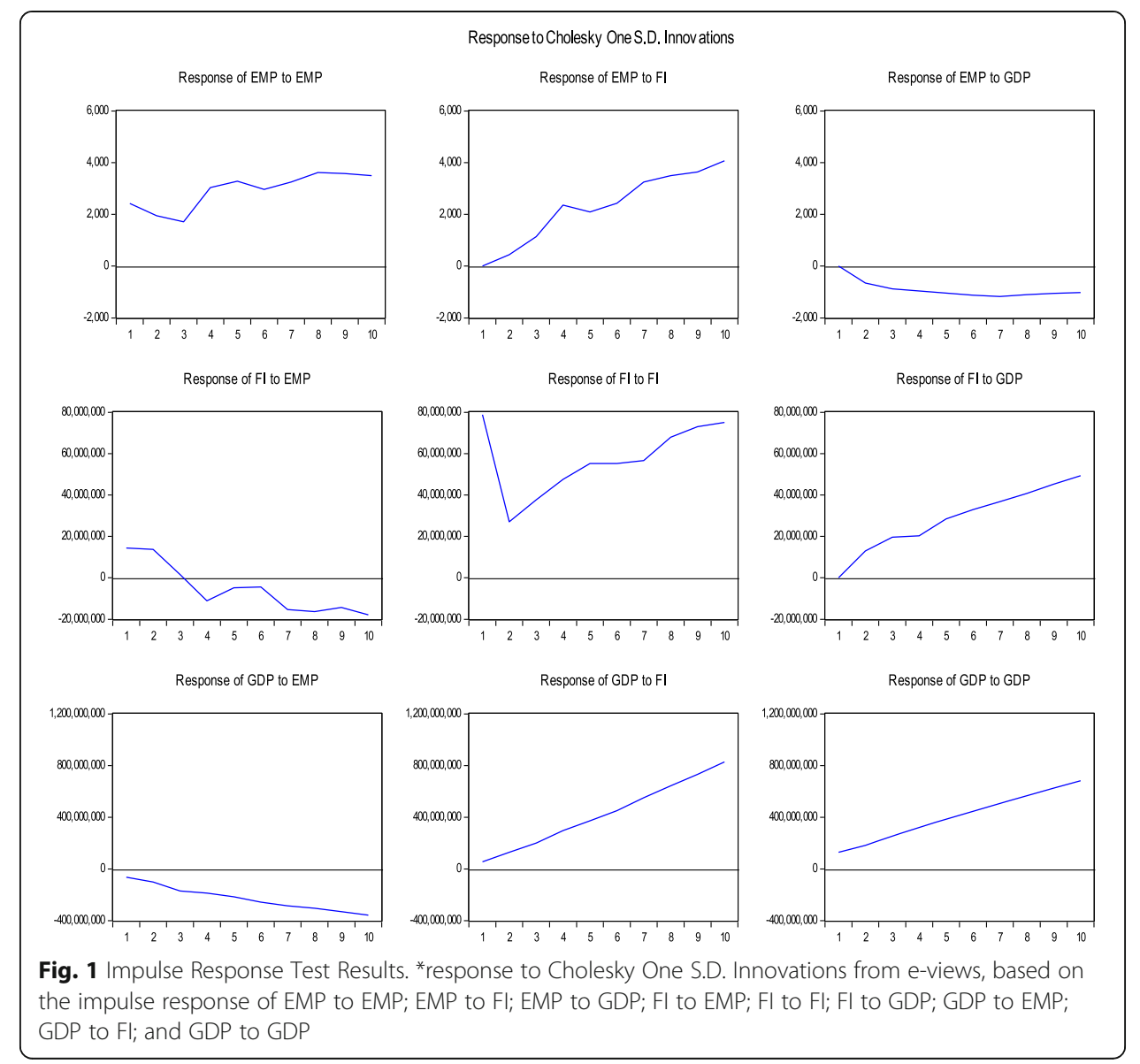

Thus, in undertaking financial reforms, extra caution must be exercised regarding the possible impact of such reforms on the level of employment. The financial sector output further reacted to the shocks of economic growth, which is linear with noticeable swings in the third and fourth period and a surge thereafter. The response of employment to innovative shocks of economic growth is negative in the first period and dissipates after the third period. Employment responded to the standard deviation in the financial sector output positively, with some swings starting at the 4th time horizon until the 8th time horizon. The response of economic growth to the employment stimuli is negative and the slope was steeper in the 1st - 3rd periods and then flatter after the 6th period. The response of economic growth to the shocks in the financial sector output is positive and the positive spike did not die out, even after the 10th period.

\section{Conclusion}

Financial institutions in North Cyprus are critical to the smooth economic transactions in that deposit money banks are efficient in ensuring the flow of funds to different economic agents. In addition, given their status as the sole player in the financial market, the banks are expected to mobilise funds and cater for both short and long-run financial needs. This paper examines the contribution of financial institutions in North Cyprus. The study utilises numerous econometric methods, which pave the way for finding the structural break in the financial sector output in 2001. This period 
corroborates with the period of financial crisis and its attendant effects witnessed in North Cyprus. The financial turmoil, which emanated from the financial crisis in Turkey, plunged the economy into recession in 2000 and 2001. Similarly, the Bai and Perron test results show breaks in financial sector output and economic growth in 1991 and 2006, respectively. The break dates corresponded with the period of Asian financial crisis in 1991 and the global economic meltdown, which begun in 2006. Thus, it seems that, although North Cyprus is isolated from world political activities, it is actually intrinsically linked to swings in the global financial markets. Evidence of the neutrality hypothesis in the finance-growth nexus was revealed. The underlying variables were weakly connected in the short-run. However, among the series in this study, economic growth responded to the short-run shocks and was able to handle the equilibrating process of reverting to the long-run trend.

This study used annual data for North Cyprus between the years 1977-2013. Data after 2013 was not available so further research can be conducted with data after the year 2013 when it becomes available. Also, as it is mentioned in literature review, there are many studies about the effect of the Financial Sector and real gross domestic product, but very few studies have been conducted based on analyzing the effects of the Financial sector output, employment, and growth. This study is unique and important for North Cyprus considering the variables used. Cross sectional or panel data analysis which includes the variety of countries using the same variables will be beneficial to explain the financial sector output, employment and economic growth.

\section{Abbreviations}

ADF: Augmented Dickey Fuller; AIC: Akaike Information Criteria; ECT: Error Correction Term; EMP: Employment; Fl: Financial Sector Output; GDP: Gross Domestic Product; PP: Philipps Perron; RGDP: Real Gross Domestic Product; SIC: Schwartz Information Criteria; SPO: State Planning Organisation; TL: Turkish Lira; VAR: Vector Auto Regressive; VECM: Vector Error Correction Mechanism

\section{Acknowledgements}

We are grateful to our respected reviewers for their valuable comments and suggestions that made a valuable contribution to improving this paper.

\section{Authors' contributions}

$\mathrm{BC}$ is the corresponding author and provided the ideas of this paper, supervised all parts of this this manuscript and revised the methodology part. SSI has performed the literature review and the methodology part of the manuscript. $\mathrm{HO}$ has revised the literature part of the manuscript. All authors read and approved the final manuscript.

\section{Funding}

Funding has not been received from any organisation.

\section{Availability of data and materials}

The data used in this manuscript is secondary data collected from the North Cyprus Prime Ministry, State Planning

Organisation. The data are available at the official web page www.devplan.org.

Ethics approval and consent to participate

Not applicable.

\section{Consent for publication}

The authors guarantee that the manuscript has not been previously published elsewhere and is not under consideration by other journals. The authors also guarantee that the manuscript is original and their own work.

Competing interests

The authors declare that they have no competing interests.

\section{Author details}

'Department of Economics, Near East University, Nicosia, North Cyprus. ${ }^{2}$ Department of Economics and Development Studies, Federal University Dutsin-ma, Dutsin-ma, Katsina State, Nigeria. 
Received: 15 March 2019 Accepted: 4 September 2019

Published online: 21 October 2019

\section{References}

Andronikou A (1979) Tourism in Cyprus. In: De Kadt (ed) Tourism: passport to development. Oxford University Press, New York, pp 237-264

Bai J, Perron P (1998) Estimating and Testing Linear Models with Multiple Structural Changes. Econometrica 66(1):47-78 Barkey HJ, Gordon PH (2001) Cyprus: The preditible crises, National Interest, 66:83-98

Baum C, Barkoulas J, Caglayan M (1999) Long memory or structural breaks: can either explain nonstationary exchange rates under the current float? J Int Finan Markets Inst Money 9:359-376

Caporale M, Rault C, Sova R, Sova A (2015) Financial development and economic growth: evidence from ten new European Union members. Int J Financ Econ 20:48-60. https://doi.org/10.1002/ijfe.1498

Chow G (1960) Tests of equality between sets of coefficients in two linear regressions. Econometrica 28(3):591-605 Retrieved from http://www.jstor.org/stable/1910133 doi:1

Christopoulous KD, Tsionas EG (2004) Financial development and economic growth: evidence from panel unit root and Cointegration testes. J Dev Econ 73:55-74

Claessens S, Demirguc-Kunt A, Huizinga H (2001) How does foreign entry affect domestic markets?, Journal of Banking and Finance 25(5):891-911

Clemente J, Montañés A, Reyes M (1998) Testing for a unit root in variables with a double change in the mean. Econ Lett 59: $175-182$

Colombage SRN (2008) Financial markets and economic performances: empirical evidence from five industrialized economies. Res Int Bus Financ 23(2009):339-348

Dickey D, Fuller W (1979) Distribution of the estimator for autoregressive time series with a unit root. J Am Stat Assoc 74: 427-431

Drake L, Hall MJB, Simper R (2006) The impact of macroeconomic and regulatory factors on bank efficiency: a non-parametric anaysis of HongKong's banking system. Journal of Banking and Finance 30: 1443-1446

Fink G, Haiss P, Vuksic G (2009) Contribution of financial market segments at different stages of development: transition, cohesion and mature economic compared. J Financ Stab 5(2009):431-455 www.elsevier.com/locate/jfstabil

Goldsmith RR (1969) Financial structure and development. Yale University, New Haven

Granger W (1969) Investigating causal relations by econometrics models and cross spectral methods. Econometrica 37:424-438

Granger W (1986) Developments in the study of Cointegrated economic variables. Oxf Bull Econ Stat 48:213-228

Granger W, Newbold P (1974) Spurious regression in econometrics. J Econ 2:111-120

Gunsel N (2006) Banking sector distress in the North Cyprus, Phd thesis, management Centre, University of Leicester, UK, p 18

Güryay E, Safakli OV, Tüzel B (2007) Financial development and economic growth: evidence from North Cyprus. Int Res J Financ Econ 8:57-62

Hamilton J (1991) A quasi-bayesian approach to estimating parameters for mixtures of normal distributions. J Bus Econ Stat 9:27-39

Islam SS, Mozumdar A (2007) Financial market development and the importance of internal cash: evidence from international data. J Bank Financ 31(2007):641-658 www.elsevier.com/locate/jbf

Johansen S, Juselius K (1990) Maximum likelihood estimation and inference on co-integration with applications to the demand for money. Oxf Bull Econ Stat 52:2169-2210

Jung W (1986) Financial development and economic growth: international evidence. Econ Dev Cult Chang 34:333-346

Kakazu H (1994) Sustainable development of Small Island Economies, Westview Press, Boulder, Colorado, pp 4-5

King RG, Levine R (1993) Finance and growth: Schumpeter might be right. Q J Econ 108(3):717-738

Kou G, Chao X, Peng Y, Alsaadi FE, Herrera-Viedma E (2019) Machine learning methods for systemic risk analysis in financial sectors. Technol Econ Dev Econ:1-27. https://doi.org/10.3846/tede.2019.8740

Levine R, Loayza N, Beck T (2000) Financial intermediation and growth: causality and causes. J Monet Econ 46:31-77

Levine R, Zervos S (1998) Stock markets, banks, and economic growth. Am Econ Rev 88:537-558

Micco A, Panizza U, Yaez M (2007) Bank ownership and performance does politics matter?, Journal of Banking and Finance 31: $219-241$

Nedjatigil ZM (1982) The Cyprus conflict. Nicosia, North Cyprus. Tezel Offset and Printing Co. Ltd., Nicosia

Okumus F, Altinay M, Arasli M (2005) The impact of Turkey's economic crisis of February 2001 on the tourism industry in North Cyprus. Tour Manag 26:95-104

Patrick H (1966) Financial development and economic growth in underdeveloped economies. Econ Dev Cult Chang 14:174-189

Phillips PCB, Perron P (1988) Testing for a unit root in time series regression. Biometrika 75:335-346

Safaklı O, Ozdeser H (2002) Analysis of North Cyprus economy. J Dogus Univ 3(1):152

Tursoy T, Faisal F (2018) Does financial depth impact economic growth, bank deposits and inflation rate in North Cyprus? Finan Innov 4(12). https://doi.org/10.1186/s40854-018-0096-y

Yartey CA (2008) Financial development, the structure of capital markets, and the global digital divide. Inf Econ Policy 20: 208-227 www.elsevier.com/locate/iep

Zivot E, Andrews D (1992) Further evidence on the great crash, the oil price shock, and the unit-root hypothesis. J Bus Econ Stat 10:251-270

\section{Publisher's Note}

Springer Nature remains neutral with regard to jurisdictional claims in published maps and institutional affiliations. 